\title{
SERUM AND TISSUE MUCOPROTEINS AND SIALIC ACID IN THYROID DISEASES
}

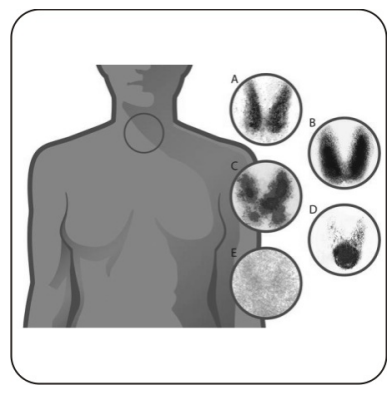

\author{
DR. ZARFAR IQBAL \\ Associate Professor, \\ Department of Biochemistry \\ Kabeer Medical College, Peshawar.
}

\author{
DR. TASNEEM ZAFAR \\ Associate Professor, \\ Department of Biochemistry \\ Wah Medical College, Wah Cantt.
}

\begin{abstract}
Objective: To find the correlation coefficient of serum mucoproteins and sialic acid to thyroid tissue in thyroid diseases. Study Design: The study was carried out at J.P.M.C, Karachi. Materials and Methods: A total of twenty four thyroid patients and twenty normal subjects were studied. The cases were divided into non toxic goiter fourteen, and toxic goiter ten on the basis of clinical and physical examination, thyroid scanning and hormone analysis. Thyroid hormones were estimated in serum. Mucoproteins and sialic acid were estimated in serum as well as in thyroid tissue. Results: Estimations of thyroid hormones and thyroxine binding globulin (T.B.G.) are useful clinically to evaluate the functions status and diagnosis of different thyroid disorders. Thyroid tissue is mainly composed of glycoprotein, thyroglobulin, and different studies showed that serum glycoprotein fractions varied in different thyroid diseases. Significantly increased levels of $T_{4}$ were observed in toxic goiter group. The levels of TBG was significantly increased in non toxic goiter, toxic goiter patients while $T_{4} / T B G$ ratio was significantly decreased in non toxic goiter. Coefficient correlation ( $r$ ) of serum to tissue mucoproteins shows an inverse relationship in non toxic goiter and toxic goiter patients. In non toxic goiter and toxic goiter patients the serum sialic acid levels to tissue sialic acid levels also shows an inverse relationship. Conclusion: Correlation coefficient analysis showed an inverse relationship of serum mucoproteins and sialic acid to thyroid tissue. It signifies that carbohydrate moieties are increased in the blood when the tissue are hyperactive and in the pathological state. It further concludes that thyrotoxic state might be converted into nodular form even into cancerous form later on.
\end{abstract}

\section{INTRODUCTION}

Thyroid glands is indispensable for the maintenance of the normal growth, development and well being of the organism. The major constituent of thyroid glands is colloid which is a large glycoprotein. Thyroglobulin which comprises $70-80 \%$ of protein ${ }^{1}$ Spiro (1965) studied the thyroglobulin of sheep, calf, pig, and human and showed that thyroglobulin is a high molecular weight glycoprotein ${ }^{2}$. The association of serum glycoproteins and mucoproteins with cancer was observed by Winzler $(1967)^{3}$.

Total protein bound carbohydrate in normal serum and its variation in different diseases like tuberculosis, 
subacute bacterial endo-carditis, advanced cancer and parenchymatous liver disease was investigated ${ }^{4,5}$. There is evidence that oncogenic transformation is associated with increased size cell surface carbohydrate ${ }^{6}$. Immunoelectrophoresis of serum of rat having inflammation induced by terpentine showed a considerable increase in mucoprotein, mucopolysaccharide and glycoprotein ${ }^{7,8,9}$.

Extensive variation in thyroglobulin structure is frequently associated with goiter and may be involved in the pathogenesis ${ }^{10}$. The level of serum thyroglobulin rises in autoimmune thyroid diseases, thyroid injury or inflammation and thyroid cancer.

Thyroglobulin provides a useful marker in thyroid toxicity to indicate recurrence of disease and for further studies and therapy ${ }^{11,12}$. Thyroxin and triiodothyronine are the only physiologically active hormones. Ratio of $\mathrm{T}_{4} / \mathrm{T}_{3}$ would be proportional to thyroid function. Estimation of $\mathrm{T}_{4}$ and $\mathrm{T}_{3}$ would be considered as better index of thyroid function as these are the basis for the grouping of the patients as non toxic to toxic form. Ophthalmopathy is clinically apparent in $20-40 \%$ of patients ${ }^{13}$. Thyroid stimulating hormone (TSH) increases the synthesis of mucopolysaccharide in the thyroid gland ${ }^{14}$. TSH induces transfer of newly synthesized protein from the follicle cells to the follicle lumen by exocytosis i.e. emptying of specific apical vesicle $e^{15,16}$.

It was also observed that a significant thyroglobulin release in man usually occurs only after intense and prolonged TSH stimulation of the thyroid gland ${ }^{17,18}$. Degree of glycosylation depends upon the concentration of plasma protein as well as amounts of sugar present in blood. Increased glycosylation of plasma proteins was noted in diabetes mellitus and this increase is directly proportional to the increase in blood glucose level ${ }^{19}$.

Thyroidectomy in man is followed by accumulation of extracellular fluid rich in hyaluronic acid containing mucoprotein and forms the basis of clinical myxoedema ${ }^{5}$.
Sialic acid N-Acety1 Neuraminic Acid, (NANA) is a component of thyroglobulin and is present at the terminal portion in the oligosaccharide chain of thyroglobulin and it is suggested that sialic acid incorporation may be used as an index for the secretion of glycoprotein ${ }^{20}$. Blahd et al $(1984)^{21}$ also observed that serum thyroglobulin levels equal to or below $20 \mathrm{ng} / \mathrm{ml}$ indicated the absence of thyroid carcinoma and values exceeding $60 \mathrm{ng} / \mathrm{ml}$ were indicative of active thyroid cancer but might include some patients without clinical evidence of disease. No study has been conducted till now both in blood and tissue level simultaneously. The purpose of this study was to estimate the levels of T4, TBG, T4/TBG variations in blood to assess the basis of toxicity. It was also planned to estimate the levels of mucoproteins and sialic acid in serum and thyroid tissue simultaneously in patients suffering from thyroid disorders which could be helpful to understand the pathogenesis of thyroid gland and it conversion into nodular and cancerous form later on.

\section{MATERIALS \& METHODS \\ Patients}

Patients suffering from thyroid disorders admitted in Surgical Units of Jinnah Postgraduate Medical Centre Karachi, Surgical Units and ENT Wards of Civil Hospital Karachi were selected. Diagnosis of the patients was carried out on the basis of history of patients physical examination and radio-isotopic studies such as thyroid scanning and Isotopic iodine uptake.

\section{Control Subjects}

Age matched subjects having no history of thyroid disease were selected from normal population. Most of the normal subjects were selected from amongst the students and staff members of Basic Medical Institute, J.P.M.C Karachi.

\section{Blood Collection}

Fifteen to twenty $\mathrm{ml}$ of blood was collected from each patient by venepuncture. About $5 \mathrm{ml}$ of blood was transferred into a clean centrifuge tube containing a mixture of sodium fluoride and potassium oxalate in a 
ratio $1: 3$ as an anticoagulant. Remaining blood was transferred to a dry centrifuge tube. Plasma was separated by centrifugation after 30 minutes of collection of blood and serum after complete coagulation of blood, approximately within one hour of blood collection. Plasma and serum after separation were transferred into dry glass bottles with plastic stoppers. $0.5 \mathrm{ml}$ of serum was stored into a plastic container for hormone analysis. All the samples were stored in the freezer at $-20^{\circ} \mathrm{C}$. Before analysis, samples were allowed to attain room temperature. Sialic acid and mucoproteins were estimated by Natelson ${ }^{23,24}$ methods respectively.

\section{Thyroid Tissue Collection}

Fresh human thyroid tissue was obtained at the time of operation and preserved in ice cold tris-hydrochloric acid buffer at $\mathrm{pH}$ 7.5. The tissue was dried on filter paper. Adherent fascia and fibrous tissue was removed. The tissue was weighed, minced and chopped. Homogenate $20 \%$ was prepared in $0.2 \mathrm{~m}$ Tris-hydrochloric acid buffer (hydroxymethyl-aminomethane $99.0-99.5 \%$ of Sigma Chemical Company, USA) at $\mathrm{pH} 7.5$ with Aloe homogenizer (Aloe Scientific company, USA). The homogenate was centrifuged at $1500^{*} \mathrm{~g}$ for 15 minutes at $4^{\circ} \mathrm{C}$ in a refrigerating centrifuge. It was labeled and stored at $4^{0} \mathrm{C}$ in a refrigerator.

\section{RESULTS}

The results are summarized in table-IV and \pm s.e.m. of each is shown. Twenty apparently healthy normal subjects and 24 patients suffering from thyroid diseases were studied. The cases were divided into two groups namely non toxic goiter (14) and toxic goiter (10). Mean values of physical findings ie. body temperature, blood pressure (systolic and diastolic) and pulse rate in different groups are shown in table-l. The mean levels of body temperature expressed in clinically euthyroid subjects i.e. controls (36.87) and in toxic goiter (36.90) were remarkably similar. In non toxic goiter patients, the mean level of body temperature $(36.75, p<0.001)$ was significantly decreased as compared with control group.

The mean levels of systolic blood pressure in non toxic goiter $(122.21, p<0.001)$ and in toxic goiter $(157.00, p<0.001)$ were significantly increased as compared with control group. The diastolic blood pressure was only significantly increased in toxic goiter $(87.50, p<0.001)$ as compered with control group (73.95). In this study, pulse rate was significantly increased in toxic goiter group $(108.00, p<0.001)$ as compared with control group. The mean values of pulse rate observed in control subjects $(74.50)$ and in non toxic goiter $(74,42)$ were remarkably similar.

\begin{tabular}{|c|c|c|c|c|}
\hline & $\begin{array}{r}\text { nysical findings } 0 \\
\text { The number of }\end{array}$ & $\begin{array}{l}\text { ts with non toxic } g \\
\text { or units are given } \\
s \text { are mean } \pm \text { s.e.n }\end{array}$ & $\begin{array}{l}\text { and control subje } \\
\text { arenthesis. }\end{array}$ & \\
\hline \multirow[t]{2}{*}{ Group } & \multirow[t]{2}{*}{ Temperature $\mathrm{C}_{0}$} & \multicolumn{2}{|c|}{ Blood Pressure } & \multirow[t]{2}{*}{ Pulse (Rate/min) } \\
\hline & & Systolic (mmHg) & Diastolic $(\mathrm{mmHg})$ & \\
\hline Control (20) & $36.87 \pm 0.02$ & $109.90 \pm 1.73$ & $73.95 \pm 1.05$ & $74.50 \pm 0.41$ \\
\hline Non toxic goiter (14) & $36.75^{\star *} \pm 0.02$ & $122.21^{* *} \pm 1.95$ & $76.78 \pm 1.19$ & $75.42 \pm 1.01$ \\
\hline Toxic goiter (10) & $39.90 \pm 0.01$ & $157.00^{\star *} \pm 6.59$ & $87.50^{* *} \pm 2.00$ & $108.00 \pm 2.70$ \\
\hline \multicolumn{5}{|c|}{${ }^{*} P<0.01$ as compared with normal control subjects. } \\
\hline \multicolumn{5}{|c|}{${ }^{* *} P<0.001$ as compared with normal control subjects. } \\
\hline
\end{tabular}


Mean values of serum $T_{4}, T B G$ and $T_{4} / T B G$ quotient are shown in table-II. The mean levels of $T_{4}$ expressed in micro $\mathrm{g} / \mathrm{dl}$ observed in control (8.17) and in non toxic goiter (7.57) were similar. The mean levels of $T_{4}$ in toxic goiter $(17.79, p<0.001)$ was significantly higher as compared with control group. The mean levels of TBG expressed as micro $\mathrm{g} / \mathrm{ml}$ in control subjects were (13.16). The significant increase was observed in non toxic goiter $(34.88, p,<0.001)$ but in toxic goiter patients $(19.13, p<0.001)$. In toxic goiter patients the mean levels were $(10.57 \pm 2.55)$.

\begin{tabular}{|c|c|c|c|}
\hline \multicolumn{2}{|c|}{ Table-II. Variations of thyroxine, thyroglobulin, and T/TBG quotient control subjects and in patients } \\
The number of patients or units are given in parenthesis. \\
The values are mean \pm s.e.m.
\end{tabular}

Table-III shows the serum mucoprotein levels in controls and serum and tissue mucoprotein levels in non toxic goiter and toxic goiter patients with their correlation coefficient $(r)$ ration. The mean levels of serum mucoproteins expressed in $\mathrm{mg} / \mathrm{dl}$ in non toxic goiter is $88.05 \pm 8.91$ and mean levels of tissue mucoproteins expressed in $\mathrm{mg} / 100 \mathrm{mg}$ of tissue in this group is $294.41 \pm$ 34.06. The correlation coefficient $(r)$ of serum mucoproteins to tissue mucoproteins in this group is 0.05. An inverse relationship was observed i.e. if the levels of mucoproteins is increased in blood then decreased levels were observed in the tissue. In toxic goiter patients mean serum mucoproteins levels and tissue levels, expressed in $\mathrm{mg} / 100 \mathrm{gm}$ of tissue are $58.21 \pm 5.61,270.17 \pm 43.91$ respectively. These findings also show an inverse relationship.

\begin{tabular}{|c|c|c|c|}
\hline \multirow[t]{2}{*}{ Group } & \multicolumn{3}{|c|}{ Mucoprotein } \\
\hline & Blood (mg\%) & Tissue (mg/100gm) & Correlation coefficient $(r)$ \\
\hline Control (20) & $67.87 \pm 47.33$ & - & - \\
\hline Non toxic goiter (14) & $88.05 \pm 8.91$ & $294.41 \pm 34.06$ & -0.05 \\
\hline Toxic goiter ()10 & $58.21 \pm 5.61$ & $270.17 \pm 34.91$ & -0.22 \\
\hline \multicolumn{4}{|c|}{${ }^{*} P<0.05,0.02$ as compared with normal control subjects. } \\
\hline \multicolumn{4}{|c|}{${ }^{* *} P<0.01$ as compared with normal control subjects. } \\
\hline
\end{tabular}


Mean levels of serum sialic acid (mg/dl) in control subjects and in non toxic and toxic goiter patients along with their tissue levels expressed in $\mathrm{mg} / 100 \mathrm{gm}$ of tissue and correlation coefficient ( $r$ ) are shown in table-IV.

Serum sialic acid level in control group is $40.83 \pm 2.03$. The mean values of serum sialic acid expressed in $\mathrm{mg} / \mathrm{dl}$ in non toxic goiter and in toxic goiter group are $55.90 \pm$ 3.19 and $55.68 \pm 2.91$ respectively. Tissue sialic acid levels in non toxic goiter is $273.69 \pm 13.91$ and values in toxic goiter are $159.26 \pm 17.57$. Correlation coefficient ( r) i.e; serum sialic acid to tissue sialic acid in non toxic goiter and toxic goiter patients are $-0.07,-0.68$ respectively. These values shown an inverse relationship.

\begin{tabular}{|c|c|c|c|}
\hline \multirow[t]{2}{*}{ Group } & \multicolumn{3}{|c|}{ Sialic Acid } \\
\hline & Blood (mg\%) & Tissue $(\mathrm{mg} / 100 \mathrm{gm})$ & $\begin{array}{c}\text { Correlation Coefficient of } \\
\text { Tissue }(r)\end{array}$ \\
\hline Controls (20) & $40.83 \pm 2.03$ & - & - \\
\hline Non Toxic Goiter (14) & $55.90^{* *} \pm 3.19$ & $273.69 \pm 13.91$ & -0.07 \\
\hline Toxic Goiter (10) & $55.68^{* *} \pm 2.91$ & $159.26 \pm 17.57$ & $-0.68^{*}$ \\
\hline \multicolumn{4}{|c|}{${ }^{*} P<0.05,0.02$ as compared with normal control subjects. } \\
\hline \multicolumn{4}{|c|}{${ }^{* *} P<0.01$ as compared with normal control subjects. } \\
\hline
\end{tabular}

\section{DISCUSSION}

Thyroid tissue mainly composed of colloid material, the major constituents of the colloid is a large glycoprotein, the thyroglobulin $(70-80 \%)$. Extensive variation in thyroglobulin are frequently found in patients with goiter which may be involved in pathogenesis and its conversion into cancerous form later on. Elevation of serum glycoprotein may arise as a result of the depolymerization of the ground substance of the connective tissue with the release of solubolized components into the circulation either in the tissue destructive processes e.g. inflammation, destructive disease, carcinoma etc. or in tissue proliferative processes e.g. prostatic hyperplasia, pregnancy, blood loss etc. ${ }^{24,25,26}$. Winzlar $(1967)^{3}$ observed significant increase in hexosamine, sialic acid, fucose and mucoproteins in advance cancer, acute tuberculosis, sub bacterial endo-carditis and parenchymatous liver diseases.

It was also found that various fractions of glycoproteins were increased in serum in different thyroid disorders, urinary stone formers and diabetics ${ }^{27,28,29}$. It has also been observed by Wade that in cancer diagnosis if serum thyroglobulin level is below $50 \mathrm{ng} / \mathrm{ml}$ residual tumor deposits are probably present and if level is above 50 $\mathrm{ng} / \mathrm{ml}$ secondary deposits are invariably present ${ }^{21}$. Thyroid hormones increases metabolism in the tissues and causes more rapid utilization of oxygen, cardiac output and heart rate ${ }^{30}$. Thyroid hormone probably has direct effect on the excitability of heart which in turn increases heart rate ${ }^{31}$.

These effects were also observed by Buccino, that thyroid hormone augments the contractile state of isolated cardiac preparations by mechanism thought not 
to involve catecholamines ${ }^{32}$. Pulse rate was significantly increased in toxic goiter $(108.00, p<0.001)$ as compared with control group. The results are in accordance with $\mathrm{Klin},{ }^{31}$. These results are also in agreement with those of Perveen and also observed by Sterling that increase may be due to super sensitivity of heart to catecholamine in hyperthyroidism and several reports indicate that the number of myocardial $\beta$-adrenergic receptors is increased $^{26,33}$.

Normally, mucoprotein serves as a cementing substance between the individual fibers of the gland tissue. The mean levels of tissue mucoprotiens expressed as $\mathrm{mg} / 100 \mathrm{~g}$ of tissue in non toxic goiter (294.41), and toxic goiter (270.17) were observed. Coefficient correlation of serum mucoprotein and tissue mucoprotein was calculated. The non toxic goiter group $(r=-0.05, P$ N. S) and toxic goiter patients $(r=-0.22, P$ N. S) showed an inverse relationship i.e. if the level of mucoproteins in blood increased there was a decrease in the tissue mucoproteins levels.

The mean levels of serum sialic acid observed in controls (40.83), . In non toxic goiter $(55.90, P<0.001)$, in toxic goiter $(55.68, P<0.001)$, the mean values were significantly higher than the controls (40.83). Sialic acid is present at terminal position in oligosaccharide chain of thyroglobulin and it is suggested that sialic acid incorporation may be used as an index for the secretion of glycoprotein ${ }^{21}$. It has also been observed that incorporation of sialic acid and iodine takes place at the same time in a newly synthesized molecules of thyrohlobulin ${ }^{20,34}$.

In this study the mean values of sialic acid in toxic goiter group is significantly higher. This may be possible that in this group the thyroid hormone formation is greater, the incorporation of sialic acid expressed as $\mathrm{mg} / 100 \mathrm{gm}$ of tissue in non toxic goiter (273.69) and in toxic goiter (159.26) were observed. Monaco reported the low contents of sialic acid in thyroglobulin of congenital goite $^{21,35}$. Correlation coefficient $(r)$ between blood sialic acid to tissue sialic acid contents were determined. It was found a negative $r$ value $(-r)$ in non toxic goiter $(r=-0.07$, $P N . S)$ and in toxic goiter ( $r=-0.68, P<0.02)$.

\section{CONCLUSION}

It was concluded from correlation coefficient analysis (blood to tissue levels) that in non toxic goiter and toxic goiter patients mucoproteins and sialic acid showed an inverse relationship. It is suggested that research may be progressed to explore the more biochemical basis for the conversion of euthyroid goiter into nodular (simple or multi nodular) goiter and even its conversion into cancerous into cancerous form.

\section{REFERENCES}

1. Degroot: L.J. and Stanbury, J, B. The thyroid and its diseases. $4^{\text {th }}$ edition. John Willey and Sons, New York, USA, 1975 ; p. 57.

2. Spiro, R.G: The carbohydrate composition of the thyroglobulins from several species. J. Biol. Chem, 1965; 240: 997-1001.

3. Winzlar, R.J: Determination of serum glycoproteins. In Methods of biochemical analysis. Ed. David Glick, Vol. II, Interscience publishers. New York, London, Sydney, 1967; PP. 279-311.

4. Ringel MD: Management of hypothyroidism in the intensive care unit. Crit. Care Clin 2001; 17:59. [PMID: 11219235] (Good overview of thyroid pathology, diagnosis, and treatment, Details the rationale and various methods of thyroid hormone replacement).

5. Wall CR: My edema coma: diagnosis and treatment. Am Fam physician 2000, 11: 2485. [PMID: 11130234] (Highlights the variable presentations of my edema coma and emphasizes the need for a high index of suspicion.)

6. Schachter, H; Glycoproteins; Their structure, biosynthesis and possible clinical implications. Clin. Biochem., 1984; 17: 3-14.

7. Dabon-Almirante CL, Surks MI: Clinical and laboratory diagnosis of throtoxicosis. Endocrinol Metab Clin North 
Am 1998; 27:25 [PMID: 9534024] (Good overview of thyrotoxicosis, out lining the clinical manifestations by organ systems.)

8. Lazarus J.H et al: Postpartum thyoiditis. Autoimmunity 2002; 35: 169. [PMID: 1239641]

9. Slatosky $\mathrm{J}$ et al: Thyroiditis differential diagnosis and management. Am. Fam physician 2000; 61: 1047. [PMID: 10706157].

10. Dunn, J. T. and Ray, S.C. Variations in the structure of thyroglobulins from normal and goitrous human thyroids. J. Clin. Endocrinol. Metab; 1978; 47: 861-69.

11. ISO Jarvi JL, et al: Thyroid function in men taking carbamazepine, oxcarbazepine, or valproate for epilepsy. Epilepsia 2001; 42: 930. [PMID: 1188894].

12. Langton JE, et al: Nonthyroidal illness syndrome: evaluation of thyroid functions in sick patients. Endocrinol Metab. Clin. North Am 2002; 31: 159. [PMID: 12055987].

13. Weetman AP: Grave's disease; N Engl. J; Med. 2000; 343: 1236. [PMID: 1107167].Lazarus JH; et al: Postpartum thyoiditis. Autoimmunity 2002; 35: 169. [PMID: 1239641].

14. Huda, A. M. S. and Rahman, M.A. Studies on mucopolysaccharide synthesis in vitro of thyroid slices. M. Phil. Thesis, Department of Biochemistry. Jinnah postgraduate Medical Centre, Karachi 1965.

15. Ekholm, R; Engstiom, G. Ericson, L.E. and Melander, A. (1975). Exocytosis of protein into the thyroid follicle lumen: An early effect of TSH. Endocrinology. 97: 33746.

16. Cooper DS: Clinical practice. Subclinical hypothyroidism. N Engl J Med 2001: 345: 260. [PMOD: 1147665].

17. Belfiore, A, Runello, F; Sava, L, Rosa, LA; G. and Vigneri, $R$. Thyroglobulin release after graded endogenous thyroglobulin stimulation in man: lack of correlation with thyroid hormone response. J. clin Endocrinol Metab. 1984; 59: 974-78.

18. Wiersinga WM: Thyroid hormone replacement therapy. Hormones; 2001: 56: 74. [PMID: 11786691].
19. Merelyn, A.M; Naughton, and Camern, D.P. Glycosylated plasma proteins: a simple method for the elimination of interference by glucose in its estimation. Clinical. Chemica. Acta. 1981; 115: 111-17.

20. Monaco, F and Robbins, J. Defective thyroglobulin synthesis in experimental rat thyroid tumor: Lack of membrane bound sialytransferase activity. J. Biol. Chem. 1973; 218: 2328-36.

21. Blahd W.H. Drickman, M.V, Porter, C.W. Hill, V.A. and Baumgartner W.A. Serum thyroglobulin a monitor differentiated thyroid carcinoma in patients receiving thyroid hormones, suppression therapy: Concise Communication. J. Nucl. Med. 1984; 25: 673-76.

22. Natelson, S. Microtechniques of clinical chemistry for the routine laboratory. $2^{\text {nd }}$ ed. Springfield, Thomas. 1961; PP. 378-80.

23. Winzlar, R.J. Devor, A.W, Mehl, J.W. and Smyth, I, M, Studies on the mucoproteins of human plasma. Determination and isolation, J. Clin. Invest. 1948; 27: 60916.

24. Kahaly GJ et al: lodide induces thyroid autoimmunity in patients with endemic goiter: a randomized, doubleblind, placebo-controlled trial. Eur J Endocrinol.1998; 139; 290. [PMID: 9758438]

25. Masiukiewicz Us. et al: Hyperthyroidism in pregnancy: diagnosis and treatment. Thyroid: 1999; 9: 647. [PMID: 10447008].

26. Perveen, F. Studies on serum glycoproteins in patients with thyroid diseases. M. Phil. Thesis, University of Karachi 1983.

27. Rahman, M. A, Rahman, B. and Perveen, S. Studies on serum mucoproteins in patients with urinary calculi. Biomed, Pharm, 1986; 40: 311-13.

28. Rehman, J: Studies on glycosylated proteins in diabetes mellitus. M. Phil thesis, University of Karachi 1983.

29. Wade, J.S.H. The management of malignant thyroid tumors, Br. J. Sur.1983; 70: 253-55.

30. Scriver $\mathrm{CR}$ et al (editions): The metabolic and molecular 
basis of inherited diseases $8^{\text {th }}$ ed. Mcgraw, Hill. 2001.

31. Klein I et al: Thyroid hormone and the cardiovascular system. N Engl J med 2001; 344: 501[PMID: 11172193].

32. Buccino, R.A. Spann, J, F. JR; Pool, P.E. Sonnenblick, $E . B$. and Braunwald. E. Influence of thyroid state on the intrinsic contractile properties and energy stores of the myocardium. J. Clin. Invest; 1967; 46: 1669-82.
33. Sterling, K. Thyroid hormone action at the cell level. N. Engl. J. Med; Med; 1979; 300: 117-23,173-77.

34. Slatosky J et al: Thyroiditis: differential diagnosis and management. Am. Fam. Physician 2000; 61: 1047. [PMID; 10706157].

35. Jaypee, text book of Medical Biochemistry $5^{\text {th }}$ eddition 2002: 05: 35-36.

\section{URO-SPECIAL CARD}

\section{URO CARD URO-SPECIAL}

Name Warda Qamar

S/o, D/o, W/o Qamar Abbas Age 22 y Sex Female Address P-92, St No. 4, Yasrab Colony, Faisalabad. No. 04

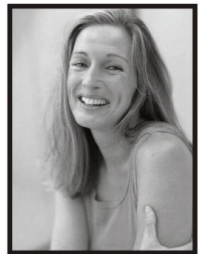

\section{Hour service available at \\ Free Consultation \\ By: \\ Consultants

